\title{
Construction of Quality Assurance System for Talent Training in Chinese-foreign Cooperative Program
}

\author{
Haiying $\mathrm{Ma}^{1, \mathrm{a}^{*}}$ and Rangjia Cai ${ }^{2, \mathrm{~b}}$ \\ ${ }^{1,2}$ School of Economics, Northwest Minzu University, Lanzhou (730124), P.R.China \\ alxmahaiying8888@163.com, b522766108 @qq.com
}

\begin{abstract}
Keywords: Chinese and foreign cooperative education; Talent training; Quality assurance; Internal and external circulation mechanism
\end{abstract}

\begin{abstract}
In view of the current Chinese-foreign cooperative program personnel training quality, the problems of surrounding the talents training goal of Chinese-foreign cooperative program, for training scheme, course system, teaching staff, teaching resources and teaching quality monitoring system for this paper. Based on Chinese-foreign cooperative program management model of the Southwest University for Nationalities, the paper uses three main body participation in cooperative program, the school of economics, institute of relying on colleges and curriculum of belonging, for each link affecting the quality of personnel training and various resources, construct the Chinese-foreign cooperative program personnel training quality guarantee mechanism of both external and internal circulation.
\end{abstract}

\section{Introduction}

Chinese foreign cooperative program is a new thing emerging in the field of education after China's reform and opening up. It has experienced more than ten years development since the early 90s of last century. In support of the state, to the education of college enrollment has expanded each year and cooperative education got legal protection under the background of the development stage of Sino foreign cooperative program of our country are facing great opportunities, from the strategy, the demand from extension to intension development based second entrepreneurial process from seeking the survival and development, that is, the pursuit of quality education.

\section{The Present Situation of the Quality Assurance System for the Talent Training}

The current Sino foreign cooperative institutions or projects running mode is becoming more diverse, the existing Sino foreign cooperative education project personnel training quality guarantee system mainly has the following problems: first, the analysis from the government level, has formulated the related evaluation system, but the project model of Sino foreign cooperation, both sides of the projects of different management modes, it is difficult to formulate measures of implementation has a guiding significance; second, analysis from the internal aspects of Chinese schools, the quality guarantee system of fostering a sound personnel have undergraduate, most are for the education system nationwide and the quality guarantee does not apply to the Chinese foreign cooperative program; third, diversified training goal of Sino foreign cooperative education project personnel the influence of the quality of talents cultivation factors is very complex, it is difficult to put forward a set of process quality can be cultivated inside The quality assurance system of the talent training of Chinese and foreign cooperative program in Colleges and universities is combined with the evaluation of the quality evaluation and the quality evaluation of the results. According to the current teaching quality of Sino foreign cooperative education project in our country, we need to make full use of the teaching quality management experience of foreign cooperation, according to foreign university education project mode, construction of training quality assurance system of Sino foreign cooperative education talent for the actual, and in this system, create own brand and the quality of colleges and universities school characteristics. 


\section{The Significance of Constructing the Quality Guarantee System for Talent Training}

The success and failure of higher education reform is based on the quality of personnel training. Through the construction of quality assurance system for Sino foreign cooperative education, it has the following functions and significance to promote teaching and improve teaching quality.

Standardizing Program. Taking teaching as the center and focusing on improving the quality of personnel training, a series of measures are adopted to gradually establish and improve an effective teaching quality monitoring mechanism and teaching management system to cover the whole process of personnel training.

Stimulate Vitality. To mobilize the two grade school to participate in internal cooperation of Sino foreign cooperative education projects (Department), positive functions, improve the quality of personnel training; to the incentives to participate in the Sino foreign cooperative education project of the teachers devote themselves to teaching and research, cultivate a batch of high-quality bilingual course of Sino foreign cooperative program; to improve the independent innovation project of Sino foreign cooperative education students learning ability.

Three Full Educating People. Establish the Sino foreign cooperative education project to cultivate the quality guarantee system and system management personnel to create a good style of study to the full participation, process monitoring, and comprehensive protection to achieve the teaching, management education, service education and environment education.

\section{The Main Content of the Construction of the Quality Guarantee System for the Talent Training}

Construction of quality assurance system is divided into two aspects of internal and external training of Sino foreign cooperative education project personnel, external level refers to attract college outside the government, industry, enterprises and foreign cooperative institutions to participate in the Sino foreign cooperative education in personnel training, they constitute the external quality assurance system in Colleges and universities and foreign cooperative education project training; the internal level refers to the Sino foreign cooperative education project is the main unit, they directly undertake the process of Sino foreign cooperative education project training.

The Establishment of the External Quality Assurance System. The establishments of external quality guarantee system mainly includes three aspects: first, the government trial project. The government establishes and improves laws and regulations concerning the field of Sino foreign cooperative program, strictly approve the examination and approval of projects, and guarantees that the target of foreign cooperation should be a reliable and reputable educational institution or body corporate in its country. Meanwhile, according to the development plan, we should consider the rational layout of disciplines, majors and regions, avoid duplication of low level projects, and select truly excellent and cooperative educational projects with complete educational quality assurance system. The second is the results of social test training. From the point of view of the industry, enterprises and other employers, the training of personnel satisfaction survey, to evaluate the effectiveness of the core curriculum of alumni (overseas education and domestic employment two) on learning in school core knowledge satisfaction survey results; three, foreign universities participate in the training process, quality monitoring course. The relatively developed countries in higher education usually have their own curriculum quality monitoring system. We should be brave enough to draw lessons from them, and let them participate in reviewing courses, evaluating teachers and evaluating management.

\section{Establishment of Internal Quality Assurance System}

Focusing on High-level Cooperation Projects. good students off all colleges and universities according to the school strength, professional characteristics of start of Sino foreign cooperative program of different levels, especially to encourage undergraduate or graduate level high level Sino foreign cooperative education project reporting work. At the same time, we need to encourage domestic high-quality applicants. Compared with pure domestic higher education, the candidates know less about cooperative education. To improve the quality of student resources cooperation, we must first strengthen the propaganda of cooperative education. From an international education perspective, 
cooperative education has more advantages than directly abroad, not only can solve the language ability and students ability to adapt to life in a large extent, avoid during the study because of learning and living difficulties caused by language barriers and cultural differences, but also shorten the time of students studying abroad, reduce the students' family economic burden. If the school can attract more high-quality students to register for examination, ensure the quality of students to ensure the quality of cooperative education, create high-quality brand cooperation projects.

Strengthening the Construction of Teaching Staff and Management Team. Set up a resource pool for Sino foreign cooperative education projects, focusing on teaching evaluation, evaluation and management, and strengthening the construction of teaching staff and teaching management team. In addition to the introduction of foreign teacher resources, domestic universities should also cultivate their competent teachers who have good foreign language level, extensive professional knowledge and certain background of foreign working practice. The school can select a batch of outstanding young teachers through international communication channels and train them to foreign related fields. At the same time, teachers who have been taught in foreign countries should conscientiously identify the qualifications and strengthen their management. To engage in cooperative education teaching management personnel to supervise their learning and understanding of foreign higher education management theory, mode, experience and practice, understand the relevant requirements of cooperative education teaching management, and through the channels of cooperation, assigned to each school or study abroad, to improve their management level. According to the majors of all Sino foreign cooperation projects, we will gradually acquire high-quality overseas teaching resources of some professional basic courses, so as to make timely supplement and timely updating of teaching resources. We should encourage the professional cooperation Institute (Department) to establish the high quality courses at all levels in the Chinese and foreign cooperative schools.

Strengthening the Quality Supervision and Management. to establish a set of suitable for the management of Sino foreign cooperative education teaching system, straighten out the internal cooperation. At the same time, standardization and scientific nature of teaching management, combined with foreign quality management requirements, quality standards and requirements of the teaching, and in strict accordance with the relevant provisions of the implementation of standards, the quality management and evaluation of partners and requirements, strengthen teaching quality all-round and whole process monitoring and management, and effectively improve the effectiveness of management and efficiency.

Carrying out Education and Teaching Activities for Teacher's Assessment. Undertaking the main task of teaching and playing a key role in the quality of teaching can make outstanding achievements in education, mechanism of teaching evaluation for teachers' teaching activities. Teaching achievement usually includes teaching practice, teacher centered teaching staff, teaching system, factors that can significantly improve educational quality and achieve training objectives. If the process of education and teaching is excellent, the quality of education must be high. At the same time, the excellent education and teaching achievements are commendation and reward, publicity, and the quality of their own brand.

\section{The Operational Objectives of the Quality Assurance System for the Talent Training}

Based on the project of Sino foreign cooperative education personnel training system construction to ensure the quality of the content, to achieve the following objectives: (1) the reasonable distinction based on the current Sino foreign cooperative education project of different levels and different majors and different modes of cooperation, training objectives clear the project professional personnel, re integration project and professional adjustment. The revised scientific training scheme, project curriculum system and teaching contents; (2) at home and abroad to make full use of high quality teaching resources, build a platform for international exchanges and cooperation, both Chinese and foreign schools play in the United to develop training programs, teaching plan and syllabus, the positive role of teacher selection, teaching quality monitoring and other fields the establishment of joint committee, management of the project; (3) the advanced teaching resources is a Sino foreign 
cooperative education project training One of the important guarantees for the quality of breeding. According to the majors of all Sino foreign cooperation projects, we will gradually acquire high-quality overseas teaching resources of some professional basic courses, so as to make timely supplement and timely updating of teaching resources. We encourage the professional cooperative schools to set up top-quality courses at all levels of Sino foreign cooperative education projects, and (4) strengthening the construction of teaching staff in universities. The introduction of foreign teachers in the selection, training, assessment and management system; to construct the training quality assurance system as an opportunity to promote talent, and cultivate a batch of master teaching methods of Sino foreign cooperative education project course teaching teacher and excellent written and spoken language teaching team; (5) the establishment of teaching quality monitoring and evaluation system. Personnel training to ensure the quality of students in the learning process, involving the whole life and development, through the construction of quality guarantee system of the Sino foreign cooperative education project personnel training, establish a quality assurance team training of Sino foreign cooperative education project personnel, including teaching management team, student management team, teaching supervision team, the quality of personnel training, part-time research team the quality of the information of the team and the students teaching information staffs.

\section{Particular Case Discussion}

Below we will with the Northwest University for Nationalities of Chinese-foreign cooperative program as an example, the deep understanding, on the basis of its management mode, explore the construction of Chinese-foreign cooperative program personnel training quality guarantee system. northwest university for nationalities is the first in Gansu province to carry out one of the schools of Chinese-foreign cooperative program, the school set up international education institute to manage and implement the Chinese-foreign cooperative program, as well as foreign student education, it's all Chinese-foreign cooperative program of the professional teaching school, the school secondary management, namely the international education institute is responsible for the school teaching management of Chinese-foreign cooperative program, making the teaching rules and regulations, manage the macro regulation and the professional cooperation school specific execution of our college (department) of relevant professional teaching management. The school unified leadership and planning, the teaching organization and student management work is mainly the international education college, the related secondary is the auxiliary management system. The government, the industry, the employer and the foreign partner constitute the external quality assurance system of Chinese-foreign cooperative programs. From the school level school of economics level constitutes the internal quality assurance system. With reference to the northwest university for nationalities Chinese-foreign cooperative program management model, it is easy to find in Chinese-foreign cooperative program personnel training work in colleges and universities of the three main economic colleges, professional relying on college and class belonging to college, we should first clarify the responsibilities of the three. the school of economics, the main responsibility is to comply with relevant documents of national ministry of education regulations, combined with the Chinese-foreign cooperative program agreement, in consultation with the foreign research, on the basis of coordination with related college of Chinese-foreign cooperative program teaching plan, prepare related course syllabus; The teaching management: in charge of Chinese-foreign cooperative program teaching task orders, course arrangement, performance management, materials management, graduation and degree awarded qualification audit and assist students admitted to the university management. The main responsibility of Chinese-foreign cooperative courses is to be responsible for the construction of Chinese-foreign cooperatively-run educational programs; Responsible for compiling the syllabus of relevant courses.

\section{Conclusions and Suggestions}

This paper stressed the responsible for completing the selection, evaluation and management of some foreign professional teachers in the project and responsible for the language teaching and strengthening 
of Chinese-foreign cooperative programs. It also needs to maintain liaison and coordination with foreign partners. To be responsible for the daily management of the middle school students. Organize and implement the relevant professional teaching activities and links: including teaching plan and syllabus, the butt joint of Chinese and foreign curriculum, teaching arrangement and organize relevant specialized teachers, course selection subscription teaching, foreign professional teachers recommend selected, etc.; Responsible for the internship practice, the implementation of graduation design and the arrangement of the exhibition venue.

\section{Acknowledgements}

This work was supported by the Pilot joint program of comprehensive professional reform of International Economics and Trade (Joint Program, USU and NWUN) (Grant No:2017XJZYZHGGSD-01) and by Research joint program on education and teaching reform (Grant No:2017XJJG-12) of the Northwest Minzu University.

\section{References}

[1] Liu Hong, Analysis and Development Countermeasures of Chinese and foreign cooperative running school, Journal of Jilin Institute of education, 3(2006).98-107

[2] Yang Jin Ping. A preliminary study on the quality assurance system of Chinese and foreign cooperation in running a school, Coal Higher Education, 3(2004)41-50

[3] Jiang Fuling, The problems and Countermeasures of Chinese and foreign cooperation in running a school, Contemporary Education Forum, 5(2007)98-110

[4] Lin Jinhui, Reasonable citation of high quality higher education resources in Chinese and foreign cooperation, Education Forum, 8 (2009)107-110.

[5] Wang Liang, Significance and implementation of teaching evaluation system in Chinese foreign cooperative education. Journal of Nanjing University of Science and Technology, 6 (2004)75-81.

[6] Li Ming, Research on internal teaching quality monitoring system in Chinese research universities. Journal of Beihang University: Social Science Edition, 1 (2014)106-107.

[7] Buddha Zhaohui, Cooperative universities construction quality assurance system at home and abroad. Research of Higher Engineering Education, 6 (2006)52-59.

[8] Dai Wei, Research on Modeling and operating mechanism of quality technology system. Quality and Reliability, 1 (2013)27-31. 